ROCZNIKI FILOZOFICZNE

Volume LXIX, issue 3-2021

DOI: https://doi.org/10.18290/rf21693-5

\title{
FROM SATAN'S WAGER TO EVE'S GAMBIT TO OUR LEAP: AN ANSELMIAN REPLY TO THE PROBLEM OF DIVINE HIDDENNESS
}

\section{INTRODUCTION}

If God exists, why is His existence open to debate? Why doesn't He make His reality patently obvious and undeniable to everyone? In other words, how is it that agnosticism and atheism are permitted to persist (indeed thrive) in a supposedly theistic world? Within the Christian tradition this sort of question boasts a long lineage, stretching all the way back to the patristic era. ${ }^{1}$ Those older discussions can mostly be seen as "in-house," intended to explore the workings of divine providence (i.e., figuring out just what God might be up to in permitting widespread nonbelief). In general they were not apologetic

Travis Dumsday, Associate Professor of Philosophy at Concordia University of Edmonton; correspondence address: 7128 Ada Blvd., Edmonton, AB, T5B 4E4, Canada; e-mail: travis.dumsday@concordia.ab.ca; ORCID: https://orcid.org/0000-0003-3374-0323.

${ }^{1}$ For relevant discussions see for instance ATHANASIUS, On the Incarnation of the Word, trans. Archibald Robertson (Buffalo, NY: Christian Literature Publishing, 1892), chap. 11-15; Augustine, On Free Choice of the Will, trans. Thomas Williams (Indianapolis: Hackett, 1993), 106-18; Dionysius the Areopagite (Pseudo-Dionysius), The Celestial Hierarchy, 260C-261D, in Pseudo-Dionysius: The Complete Works, trans. Colm Luibheid (Mahwah, NJ: Paulist Press, 1987), 171-73; Gregory NAZIANZuS, Orations, trans. Charles G. Browne and James E. Swallow (Buffalo, NY: Christian Literature Publishing, 1894), oration 28, chap 12; John Chrysostom, Homilies on First Corinthians, trans. Talbot W. Chambers (Buffalo, NY: Christian Literature Publishing, 1889), homilies 2 and 4-8; John Damascene, On the Orthodox Faith, in Writings, trans. Frederic Chase (Washington, DC: Catholic University of America Press, 1958), bk. 1, chap. 3; Maximus the ConfEssor, On Difficulties in Sacred Scripture: The Responses to Thalassios, trans. Maximos Constas (Washington, DC: Catholic University of America Press, 2018), 82-87; ORIGEN, On First Principles, trans. Frederick Crombie (Buffalo, NY: Christian Literature Publishing, 1885), bk. 3, chap. 1. 
exercises intended to address the concerns of non-Christians, though they could be seen as having some implications for that arena. By contrast, in the recent literature this sort of question has mostly shifted its dialectical context, so that it is discussed primarily as an argument for atheism referred to as the "problem of divine hiddenness" (PDH). Its core line of reasoning might be summed up in different ways, but here is one way to formalize it as a simple modus tollens:

Premise 1: If God really existed, then there would be few (if any)

blameless agnostics and atheists.

Premise 2: But there are lots of blameless agnostics and atheists.

Conclusion: Therefore, God does not really exist.

Let us clarify some of the terms at issue. First, the deity targeted by the argument is the Judeo-Christian God. There is a case to be made for the applicability of this argument (or some close analogue) to the deities of other religious traditions, but the contemporary hiddenness literature is mostly focused on God as conceived by the Jewish and Christian theological traditions (with the differences between those traditions being irrelevant in this context). Second, the sense of "blameless" here is of course not "blameless in every way" but rather "blameless with respect to their agnosticism or atheism." The idea is that for at least some of those lacking theistic belief, that lack is not due to any fault on the part of the nonbeliever. Maybe the nonbeliever lacks belief in God because he was raised by thoroughgoing Freudians, or because he was brought up in a predominantly Theravadan Buddhist culture in which no divinities of any kind were recognized, or perhaps because he never heard of God at all (at least not in such a way as to understand the concept behind the label), or perhaps he was aware of and understood this concept but due to honest and principled intellectual reservations (perhaps a prolonged and deep reflection on the problem of evil?) declined to affirm the existence of such a Being. In any case, this nonbeliever is not refusing to believe in God because of conscious or unconscious rebellion, nor is he resisting God out of a desire to continue wallowing in sin, nor is he falling prey to irrational cognitive biases for which he bears some indirect responsibility. Instead, he is genuinely a "nonresistant nonbeliever" or "inculpable nonbeliever" (two labels that have been employed in the literature) or, in the language employed above, a "blameless agnostic or atheist." Third, the qualifying wording of "few (if any)" is meant to flag an area of disagreement amongst proponents of the PDH. Some hold to quite a robust version of the argument, according to which any occurrence 
of nonresistant nonbelief, on the part of anyone, for any length of time, disproves theism. The most steadfast defender of this version of the argument (and indeed the single most important proponent of the PDH) is J. L. Schellenberg. ${ }^{2}$ By contrast, other advocates of the PDH hold to a weaker formulation, according to which the sheer amount of nonresistant nonbelief constitutes the real problem for theism. On this alternative reading, some small number of blameless agnostics or atheists might conceivably be explicable by the theist, but there is no way that a loving God would permit the uncountably massive quantities of nonresistant nonbelief actually found in our world today and in the past. ${ }^{3}$

Having clarified the terminology in play, let us briefly consider some of the justifications put forward on behalf of the premises. The case for premise 2 can be summed up in a single word: observation. There do seem to be a great many blameless agnostics and atheists out there. You probably know some. Maybe you are one. Of course, the reality and/or commonality of blameless nonbelief can be disputed, and has been. ${ }^{4}$ Still, the debate over the PDH has mostly centered around premise 1, the most common justification for which runs roughly as follows: God is supposed to be morally perfect and hence perfectly loving. So God must love us. But if He truly loved us, then He would ensure that those of us willing and able to engage in a positive conscious personal relationship with Him would, at all times, be able to do so. (Why? Because having such a relationship is ultimately necessary for our personal well-being/happiness, and also because it is of the very nature of love always

\footnotetext{
${ }^{2}$ Schellenberg's many works on the PDH include the following books: Divine Hiddenness and Human Reason (Ithaca, NY: Cornell University Press, 1993); The Wisdom to Doubt: A Justification of Religious Skepticism (Ithaca, NY: Cornell University Press, 2007); and The Hiddenness Argument: Philosophy's New Challenge to Belief in God (Oxford: OUP, 2015).

${ }^{3}$ Advocates of this version of the PDH include Theodore DRANGE, "The Argument from NonBelief," Religious Studies 29, no. 4 (1993): 417-32, and Nonbelief and Evil: An Argument for the Nonexistence of God (Amherst, NY: Prometheus, 1998); James Keller, "The Hiddenness of God and the Problem of Evil," International Journal for Philosophy of Religion 37, no. 1 (1995): 13-24. Note that while Keller rejects Christian theism, he remains open to alternative models of God (notably process theism) and so his version of the PDH is intended to push in that direction rather than toward outright atheism. Another interesting variant of the PDH is that of Stephen MAITZEN, who argues that the fact of there being whole cultures ignorant of God creates a uniquely troubling problem for traditional theism. See his "Divine Hiddenness and the Demographics of Theism," Religious Studies 42, no. 2 (2006): 177-91.

${ }^{4}$ See Douglas HenRY's papers challenging this aspect of the PDH: "Does Reasonable Nonbelief Exist?" Faith and Philosophy 18, no. 1 (2001): 75-92, and his "Reasonable Doubts about Reasonable Nonbelief," Faith and Philosophy 25 (2008): 276-89. See also Elizabeth JACKSON's more recent treatment of premise 2 in her "Wagering against Divine Hiddenness," European Journal for Philosophy of Religion 8, no. 4 (2016): 85-108.
} 
to seek open relationship with the object of love.) Yet engaging in such a relationship requires first believing that God exists, for how could we possibly have a personal relationship with someone whose very existence was in doubt (let alone someone whose existence we were wholly ignorant of)? And so God would ensure that all those willing and able to engage in a positive conscious personal relationship with Him would, at all times, have a rationally indubitable belief in His reality. How would He do so? Who knows - there are plenty of potential options open to an omnipotent being, ranging from periodic worldwide miracles, to blatantly obvious teleological signs (e.g., the proverbial arranging of the stars to spell out (in English?) "God exists"), to overwhelmingly compelling personal religious experiences bestowed upon us beginning from a very young age, to a sensus divinitatis implanted in our intellects blocking out the possibility of rational doubt about theism, and so on. Yet, as we learned in premise 2, that is not the world we live in-far from it, there are in fact plenty of blameless agnostics and atheists out there, and apparently plenty of room for rational doubt about theism. And so God does not exist.

That is a very brief rundown of the argument, and I have skipped over a number of complexities and qualifications that would have to be brought up in a more complete overview - complexities such as the precise notion of "love" at work in the justification for premise $1,{ }^{5}$ or the issue of whether an omnipotent God really could ensure that all room for rational doubt about theism was wholly removed, ${ }^{6}$ and so on. But hopefully the preceding will suffice for present purposes.

A substantial literature has arisen exploring the many avenues of reply to the PDH, and the counter-replies to those replies. While some of this literature has mined historical sources for insights, in particular sources from the

\footnotetext{
${ }^{5}$ For a discussion of this see Ebrahim AzADEGAN, "Divine Love and the Argument from Divine Hiddenness," European Journal for Philosophy of Religion 6, no. 2 (2014): 101-16.

${ }^{6}$ This issue is trickier than one might initially suppose, and is taken up in detail by Rolfe KING, Obstacles to Divine Revelation: God and the Reorientation of Human Reason (London: Continuum, 2008). In this important (and oddly neglected) book, King makes the case that all of the modes of divine revelation mentioned above (worldwide miracles, blatant teleology, ubiquitous powerful religious experiences, universally implanted belief), among others, would unavoidably still leave room for rational doubt (and by extension nonresistant nonbelief). If King is correct about this, it would go a long way to defusing the PDH as an argument for atheism (though it might also raise interesting complications for some theists' larger enterprise of natural theology).
} 
mediaeval ${ }^{7}$ and early modern periods,${ }^{8}$ there is much left to be done here. This article is intended to contribute to this still-modestly-sized byway within the hiddenness literature, by exploring some relevant ideas from the writings of St. Anselm.

The remainder is divided as follows: in the next section I summarize Anselm's model of the fall of Satan, focusing on his crucial (for our purposes) understanding of the devil's epistemic status prior to that fall. Then in the third and final section I draw out some potential implications of that model for a larger Anselmian understanding both of humanity's initial fall and of the present-day epistemic status of blameless agnostics and atheists. I further explain how these Anselmian insights might be put to work today in the form of an explicit reply to the PDH. However, in the end I also suggest that while these insights may prove helpful for some philosophers working on the $\mathrm{PDH}$, it is likely that they will be of greater interest to theologians pursuing the aforementioned older, patristic mode of questioning about the workings of providence.

\section{ANSELM ON THE DEVIL'S FALL}

Anselm laments the fact that God is not openly present to us in a clear and obvious way. In the first chapter of his Proslogion he writes:

Lord, if you are not here, where shall I seek you, since you are absent? But if you are everywhere, why do I not see you, since you are present? Truly "you dwell in unapproachable light." "And where is this "unapproachable light"? How am I to approach an unapproachable light? Who will lead me into it, so that I can see you in it? And by what

${ }^{7}$ For some (very different) attempts to appropriate the thought of St. Thomas Aquinas in this context see the following: Travis DumsDay, "A Thomistic Response to the Problem of Divine Hiddenness," American Catholic Philosophical Quarterly 87, no. 3 (2013): 365-77; Roberto Di Ceglie, "Christian Belief, Love for God, and Divine Hiddenness," Philosophia Christi 18, no. 1 (2016): 179-93; and G. P. MARCAR, “Aquinas' Quinque Viae: Fools, Evil, and the Hiddenness of God," Heythrop Journal 56 (2015): 67-75.

${ }^{8}$ See Sarah COAKLEY, "Divine Hiddenness or Dark Intimacy? How John of the Cross Dissolves a Contemporary Philosophical Dilemma," in Hidden Divinity and Religious Belief: New Perspectives, ed. Adam Green and Eleonore Stump, 229-45 (Cambridge: CUP, 2015); Laura GARCIA, "St. John of the Cross and the Necessity of Divine Hiddenness," in Divine Hiddenness: New Essays, ed. Daniel Howard-Snyder and Paul Moser, 83-97 (Cambridge: CUP, 2002); Thomas V. MORRIS, Making Sense of It All: Pascal and the Meaning of Life (Grand Rapids, MI: Eerdmans, 1992); V. Martin NemOIANU, "Pascal on Divine Hiddenness," International Philosophical Quarterly 55, no. 3 (2015): 325-43; and Tyler Paytas, "Of Providence and Puppet Shows: Divine Hiddenness as Kantian Theodicy," Faith and Philosophy 36, no. 1 (2019): 56-80.

${ }^{9}$ This line references 1 Timothy 6:16. 
signs am I to seek you? Under what aspect? I have never seen you, O Lord my God; I do not know your face. What shall he do, O Lord Most High? What shall he do, this distant exile from you? What shall your servant do, deeply troubled by his love for you and "banished far from your face"? ${ }^{10} \mathrm{He}$ longs to see you, but your face is too far away from him. He desires to approach your presence, but your dwelling is unapproachable. He wants to find you, but he does not know where you are. He aspires to seek you, but he does not know your face. Lord, you are my God, and you are my Lord, but I have never seen you. You have made me and remade me, you have given me every good thing that is mine, and still I do not know you. I was created so that I might see you, but I have not yet done what I was created to do. How wretched human beings are! They have lost the very thing for which they were created. Hard and terrible was their fall! ${ }^{11}$ [Emphasis added]

Towards the end of that same chapter he adds: "I acknowledge you, Lord, and I thank you, that you have created in me this image of you so that I may remember you, think of you, and love you. Yet this image is so eroded by my vices, so clouded by the smoke of my sins, that it cannot do what it was created to do unless you renew and refashion it." 12 But although Anselm recognizes that our fallen state involves being cut off from direct experiential contact with God, and thus impacts our epistemic state vis a vis the divine, he does not grant the further idea that God's very reality is open to rational doubt (upon adequate reflection); in fact he remains confident that by reason alone we are still capable of recognizing that such a Being must exist. This confidence is on display in the opening sentence of the first chapter of his Monologion:

If anyone does not know, either because he has not heard or because he does not believe, that there is one nature, supreme among all existing things, who alone is self-sufficient in his eternal happiness, who through his omnipotent goodness grants and brings it about that all other things exist or have any sort of well-being, and a great many other things that we must believe about God or his creation, I think he could at least convince himself of most of these things by reason alone, if he is even moderately intelligent. ${ }^{13}$

As such Anselm would likely deny the truth of premise 2 of the PDH: God's reality is, for him, rationally knowable, even if God's presence remains experientially elusive in this life due to the fall. And so he would probably affirm that anyone persistently lacking basic theistic belief does so out of spiritual sloth or culpable indifference or sinful resistance to God's renewing grace (or a combination of such factors).

\footnotetext{
${ }^{10}$ From Psalm 51:11.

${ }^{11}$ Thomas Williams, trans., Anselm: Basic Writings (Indianapolis, IN: Hackett, 2007), 79.

12 Ibid., 81 .

${ }^{13}$ Ibid., 7.
} 
Those facts might incline the modern reader to think that Anselm cannot have anything helpful to say about the $\mathrm{PDH}$, at least pertaining to its first premise. Yet such a dismissal would be premature, for there are other aspects of Anselm's thought that will prove relevant to evaluating Premise 1. To show this, we first have to delve into a portion of his system that might initially seem rather far outside our concerns: namely, his views on the fall of Satan.

To begin, Anselm is, on the whole, a proponent of libertarian free will. ${ }^{14}$ Angels were initially brought into existence in a state of genuine freedom and moral rectitude. It was up to them to accept God's grace freely and thereby to persevere forever in that original rectitude of will, always choosing as they ought. Yet as a matter of fact in the angelic realm Satan instead freely sinned, followed by a host of lesser angels, who all thereby constituted themselves as fallen angels (i.e., demons). Once they fell, their wills became permanently and irreparably fixed in sin. Though inherently free, having once made their choice they effectively became slaves to sin. (Anselm uses the analogy of a free man selling himself into slavery. Once the act is committed, there is a sense in which he remains inherently free insofar as he still possesses a will of his own, yet he cannot efficaciously choose to extricate himself from his newly enslaved condition.) ${ }^{15}$ By contrast, once the good angels opted for allegiance to God instead of sin, they were permanently confirmed in moral rectitude, while remaining inherently free. Much the same picture applies to our first ancestors: Adam and Eve were brought into the world free and morally upright, but then freely fell into sin and thereby became slaves to it. Yet unlike the fallen angels, their sinful condition was by divine decree susceptible of healing by divine grace, at least during earthly life. With the help of divine graceand, ultimately, the incarnation and cross - Adam and Eve could freely repent

${ }^{14}$ On this topic see especially Katherin RogERs, Anselm on Freedom (Oxford: OUP, 2008), and Freedom and Self-Creation: Anselmian Libertarianism (Oxford: OUP, 2015). Rogers has long advocated viewing Anselm as supplying a unique and fairly comprehensive philosophical system, one which is different in key respects from later and better-known Scholastic systems (e.g., Thomism), and which remains independently defensible today. See also her earlier books Perfect Being Theology (Edinburgh: Edinburgh University Press, 2000) and The Neoplatonic Metaphysics and Epistemology of Anselm of Canterbury (Lewiston, NY: Edwin Mellen Press, 1997).

${ }^{15} \mathrm{He}$ says the following in his dialogue On Freedom of Choice: "For if someone has the power not to be a slave, and no one else has the power to make him a slave, although he can be a slave through his own power, then as long as he exercises his power not to be a slave rather than his power to be a slave, nothing can master him and make him a slave.... Even though they [the sinful angels] had subjected themselves to sin, they could not destroy the natural freedom of choice within themselves. What they could do, however, was to make themselves unable to exercise that freedom without some additional grace that they had not had before" (WiLliams, Anselm, 149). 
and return to a state of rectitude. (Though according to Anselm if we die in unrepentant sin, we are permanently lost, reverting to a state just as hopeless as that of the irremediable demons.) The resulting taxonomy of freedom-inrelation-to-salvation is a bit complex, but he concisely summarizes it towards the end of his dialogue On Freedom of Choice:

There is a freedom of choice that is from itself, neither made by nor received from anyone else; it belongs to God alone. There is another freedom of choice that is made by and received from God; it belongs to angels and human beings. The freedom that is made or received either has rectitude that it preserves, or lacks rectitude. That which has rectitude has it either separably or inseparably. That which has rectitude separably belonged to all the angels before the good were confirmed and the bad fell, and it belongs now to all human beings before death who have rectitude. That which has rectitude inseparably belongs to elect angels and human beings - but to angels after the fall of the reprobate and to human beings after their death. Now that which lacks rectitude lacks it either recoverably or irrecoverably. That which lacks it recoverably belongs only to human beings in this present life who lack it, although many do not recover it. That which lacks it irrecoverably belongs to reprobate angels and human beings-but to angels after their fall, to human beings after this life. ${ }^{16}$

This much will be familiar to most readers, insofar as Anselm is largely following older Augustinian conceptions of soteriology (though he is arguably more of a libertarian than Augustine, with differing ideas about predestination). ${ }^{17}$ Not all of the details of that picture will be important for our purposes; in particular, the questions of whether demons are hopelessly damned, or whether humans dying in sin are likewise hopelessly damned, or whether in general hell is an everlasting state for any rational creature, can all be left open. So can the question of whether a fallen human is ipso facto a "slave to sin" (as Anselm understands this). Those aspects of Anselm's model will not be relevant here (though they are obviously important in and of themselves). What will be relevant are his claims that angels and the first humans were created free and righteous, that some of the former and all of the latter freely fell, and that whether they were irreparable or reparable both falls were disastrous - morally heinous events that cast a pall over creation itself.

Now consider a further question: Why did God grant angels and humans freedom in the first place, given the risks it entailed? Anselm has an answer for this, namely that "freedom of choice was given to the rational nature in

\footnotetext{
${ }^{16}$ Ibid., 165.

${ }^{17}$ See for instance his remarks in On the Harmony of God's Foreknowledge, Predestination, and Grace with Free Choice, question 2 (found in WiLliams, Anselm, 372-74).
} 
order that it might preserve the rectitude of will it had received.... Justice is rectitude of will preserved for its own sake. But we believe that freedom of choice contributes to justice. Therefore, we must unhesitatingly assert that the rational nature received freedom for no other purpose than preserving rectitude of will for the sake of rectitude itself." 18 This too will be a familiar idea to most readers: in the creaturely realm, moral rectitude ultimately involves choosing rightly because it is right. Theoretically perhaps, God could have created a being with a will of some sort, but which was, from its beginning, fixedly ensconced in righteousness. Maybe God could have created a world where the only rational creatures were beings of this sort. But such a world would have been lacking in an important good, which Anselm here labels "justice": the good of opting for continued rectitude precisely because it is right, not because it is advantageous to the agent or because there is no ability to do otherwise. From Anselm's perspective a world is better off containing justice and truly just agents even if that means an attendant risk of sin. This is a superior state of affairs than one containing no risk of sin and correspondingly a merely robotic righteousness, pre-programmed and irresistible. In the fifth chapter of his dialogue On the Fall of the Devil he writes as follows concerning the good angels who refrained from sin and so never fell:

You know for certain that if they were not able to sin, they preserved justice out of necessity and not in virtue of their power. Therefore, they did not merit grace from God for remaining steadfast when others fell any more than they did for preserving their rationality, which they could not lose. Nor, if you consider the matter rightly, could they properly be called just.... So suppose that those who fell had not sinned, even though they were able to. They would have been greater than the angels who were not able to sin, insofar as they would have been genuinely just and would have merited grace from God.... Therefore, the good angels were able to sin before the fall of the evil angels, just as has been shown in the case of those who fell. ${ }^{19}$

That kind of claim has of course been much-disputed-e.g., in the literature on the problem of evil it is often countered that giving up something like Anselmian justice + angelic/human freedom would have been a small price to pay for a pristine world wholly devoid of evil. On this view, if "genuine justice" and liberty have to be sacrificed to make reality safe from horrors, so be it. Normative intuitions differ here. Still, most would grant that Anselm's view on this is at least not patently unreasonable; many do seem disinclined

\footnotetext{
18 Williams, Anselm, 151.

${ }^{19}$ Ibid., 179-80.
} 
to give up on libertarian free-will, whatever the compensations on offer. So let us suppose that he is correct, that this is at least part of the reason why the angels and our ancestors were granted such freedom. Now consider another question: Why would any free being, brought into existence in a state of moral rectitude and with an awareness of God, choose to sin? This is a deep question (arguably a deep mystery), but a key part of Anselm's answer is uncertainty. The angel that would become the devil knew by direct personal experience that God existed and what God was like. He also knew his moral duties, and the fact that it was possible to violate them for the sake of personal advantage. ${ }^{20}$ What he did not know was just what would happen to him if he violated them. He knew that, morally speaking, he would deserve to be punished, but he did not know that he actually would be-or, if so, what the nature of the penalty would be. All of this knowledge was inaccessible, and God opted not to reveal it to him or any of the angels. This was to ensure their ability to choose justice for the sake of justice rather than for the sake of advantage. That is, if they knew that transgression would merit eternal and irrevocable damnation, then fear and rational self-interest would have kept them in line, and so they would have been denied the opportunity for meaningful moral choice (and the manifestation of true justice) just as certainly as if they had never had free-will in the first place. Let us refer again to On the Fall of the Devil, this time from chapter 23:

Just as it is certain that he must have known he would deserve punishment if he sinned, so also he should not have known that he would be punished if he sinned.... Because he was rational, he was able to understand that it would be just for him to be punished if he sinned. But since God's "judgements are a great abyss" and "his ways are unsearchable, ${ }^{21}$ the angel could not have known for certain whether God would in fact do what he could justly do. Suppose someone were to say this: "There is no way the angel could have believed that God would damn his own creature, which he had made out of his great goodness, because of the creature's fault — especially since there had been no example of avenging justice prior to the angel's injustice."... Let's return to what I had said, namely, that he should not have had this knowledge, since if he had known this,

\footnotetext{
${ }^{20}$ The devil's choice was somehow between justice and advantage, but in this dialogue Anselm leaves open the question of precisely what kind of advantage the devil could have been seeking through his act of sin. In the dialogue the student asks: "But if you can tell me, I would like to hear what sort of advantageous thing this was that the good angels justly spurned and thereby advanced, and the evil angels unjustly desired and thereby fell away." The teacher replies: "I don't know what it was. But whatever it might have been, all we need to know is that it was something they were able to attain, which they did not receive when they were created, in order that they might advance to it by their own merit" (WILliams, Anselm, 180-81).

${ }^{21}$ These are lines from Psalm 36:6 and Romans 11:33, respectively.
} 
he, as one who both willed and had happiness, could not have spontaneously willed that which would make him wretched. Therefore, he would not have been just for not willing what he ought not, since he would not have been able to will it... But if he had refrained from sinning out of fear, he would not be just. ${ }^{22}$

The basic idea here, namely that some degree of ignorance is required in order to preserve the meaningful exercise of free moral choice in finite rational creatures, is of course taken up again in later philosophical history, with some solutions to the PDH involving the claim that certainty about the reality of an all-knowing, all-powerful and perfectly just Judge could wreck our ability to choose freely between good and evil - certainty about the reality of such a God could compel good conduct out of rational fear of punishment. ${ }^{23}$ Anselm both foreshadows this approach and departs from it, agreeing on the key role of uncertainty in this domain, but disagreeing about whether ignorance of God's existence is required. One can imagine someone maintaining, against Anselm, that a rationally calculating proto-devil would surely recognize that, given God's obvious existence, sin carried too great a risk to render rational any wager against the prospect of divine punishment (no matter how appealing the advantages apparently entailed by the sin). But then, as Anselm points out in that last quote, one can also imagine a proto-devil weighing up the prospects of divine mercy (indulgence?) and betting in that direction instead. And since when was the commission of evil a wholly rational exercise?

For now, leave aside the question of whether Anselm's view on this matter is more plausible, and recall that the Biblical depiction of the fall of Eve and Adam provides another kind of theological test-case or thought experiment to contemplate in this context. In the next section we will do just that, in dialogue with Anselm and with an eye to premise 1 of the PDH.

\section{EVE, ADAM, AND US}

The Bible provides us with little data concerning the devil's fall, whereas the data on the fall of Eve and Adam is comparatively robust. We all know the story: God places our two forebears in a paradisiacal garden, asking of them only that they tend it, multiply themselves, and stay away from a single

\footnotetext{
${ }^{22}$ Ibid., 206.

${ }^{23}$ Recent authors who have advocated a similar solution to the PDH include Michael MURRAY, "Deus Absconditus," in Divine Hiddenness: New Essays, ed. Daniel Howard-Snyder and Paul Moser (Cambridge: CUP, 2002), 62-82; see also Richard SwINBURne, Providence and the Problem of Evil (Oxford: OUP, 1998), 203-10, and The Existence of God, 2nd ed. (Oxford: OUP, 2004), 267-72.
} 
tree, namely the tree of the knowledge of good and evil. If they eat its fruit, they will die (though the nature and timing of that death are not spelled out). The snake, whom tradition has tended to equate with the devil, approaches Eve and tempts her to eat the fruit anyway. He tells Eve that, far from dying, she will become like God, knowing good and evil. Essentially, he is calling God a liar and asking Eve to accept this impugning of the divine character. She takes a gambit that the serpent is telling the truth and God was not, eats the fruit, and then with a bit of prompting gets Adam to do the same. The rest is history-we as their progeny get born into a death-prone fallen world well outside the flaming-sword-guarded garden.

How much of this Biblical narrative is literal history versus symbolism and/or allegory can be left aside for the moment. The point of interest for us lies in the fact that, when read in conjunction with Anselm's model of Satan's fall, the narrative provides a potential rerun of the ignorance-as-freedom-preserving proposition, though in a notably different form. As we've seen, according to Anselm God gave the pre-fall devil at least three relevant pieces of knowledge: (a) a knowledge of God's existence and nature; (b) a knowledge of his own moral duties; and, (c) a knowledge that the breach of those duties would entail that punishment would be deserved. What the devil lacked was a fourth piece of knowledge: (d) a knowledge that he really would be punished, and in precisely what way. Thanks to his uncertainty about point (d), the devil retained his freedom, and unfortunately abused it. Now what do we have in the story of Eve's temptation and fall? Well, we see Eve having the advantages of (a)-(c), just like the pre-fall devil, but also apparently the advantage of possessing (d). God told her that she would be punished, and in what manner. Yet still she sinned, and Adam too. Does this not cause a problem for Anselm's model of Satan's fall? After all, Eve remained free even with complete information packet (a)-(d), so how could the lack of (d) have been crucial in preserving Satan's freedom?

Anselm was of course well aware of the Biblical account of humanity's fall, and seemingly sees no contradiction between it and his own model of the role of ignorance in Satan's fall. One way to reconcile the two is to notice that the absence of (d) in the devil's case is not quite the same as the presence of (d) in Eve's. In recognition of this distinction, let us call the latter (d)*. When Anselm is talking about the devil's uncertainty regarding the punishment for his sin, the presumed contrast is with a situation where the devil knows with certainty the reality and nature of his punishment for sin. Certain knowledge, according to Anselm, would have hijacked free moral choice in this case. So 
the hypothetical presence of (d) to the devil would have involved certainty of punishment, whereas clearly the actual presence of (d)* to Eve did not involve certainty of punishment. We know it did not, because if Eve had been certain about her punishment then she would not have been at all vulnerable to the serpent's deceptive coaxing. God said she would be punished, the serpent said she would not, and she gambled on the serpent. In other words, God informed her in advance of her punishment, but in such a way that she was free to disbelieve him (sinfully). By contrast, the sort of situation Anselm envisages in the devil's case is one in which the information would have been communicated in an absolutely indubitable fashion. (How exactly would God have communicated it to the devil in a manner that would have been more convincing than the communication to Eve? Anselm does not tell us, though we can imagine scenarios: perhaps something like verbal communication + some sort of infallible prophetic insight on the point?) Although there crucially remains uncertainty in both the devil's case and Eve's, it is noteworthy that in a sense Eve is granted substantially more in the way of information: with (d)* she is explicitly told that she will be punished, and how she will be punished. That is information not given to the pre-fall devil. It is as if God is trying a different strategy in humanity's case, granting still more information to see if it might help avoid the disaster previously experienced with the fallen angels, while still not granting so much knowledge as to remove moral freedom. Tragically this extra help does not help, but presumably it was worth a try.

So the Biblical narrative of humanity's fall does actually accord with Anselm's model of Satan's fall and his related claim about the need for uncertainty in preserving moral freedom (and thus true justice). Now suppose for the sake of argument that Anselm's model of Satan's fall is correct, or at least the (a)-(c) minus (d) epistemic aspect of that model. Suppose further that however much of the Biblical narrative of humanity's fall is historical, at least the epistemic aspect of it we have been discussing is historical-one of our early ancestors was faced with a moral test and the accompanying epistemic structure of (a)-(c) plus (d)*, which was an improvement over the epistemic situation previously faced by the angels. Now consider the resultant state of affairs from a God's eye point of view, as it were: two kinds of free rational creature have been created. A substantial chunk of the membership of the first kind fell into sin and became irrevocably (perhaps?) lost demons. The entirety of the more limited early membership of the second kind fell into sin and became lost-remediably lost, granted, but where the only available method of redemption is infinitely costly (recall that Anselm thinks the incarnation 
and cross are the only possible method of human redemption, a point made clear in his Why God Became Man, book 2, chapters 6-7). ${ }^{24}$ Both falls took place in epistemic situations in which the members of these kinds were granted a great deal of information that ought to have been helpful, with early humans in particular being granted as much helpful knowledge as they possibly could be granted, knowledge just short of hijacking their moral freedom.

So near-maximal knowledge-consistent-with-freedom did not forestall an angelic fall, and maximal knowledge-consistent-with-freedom did not forestall a human fall. Consider now the status of us, Adam and Eve's fallen descendants (or, if you prefer, the fallen descendants of an anonymous band of homo sapiens tens of thousands of years ago blessed with the first-ever awareness by biological entities of God and the moral law). With all that historical baggage in mind, what should God do vis a vis our epistemic state?

Well, we have seen the answer given by the proponents of the PDH: a loving God should give absolutely all of us a rationally indubitable knowledge of His existence, provided that at the moment we are (just like Eve was) open to engaging Him in a positive relationship (i.e., not at present actively resisting it or rejecting it). The fact that any of us - or, for some PDH advocates, the fact that so many of us - lack such knowledge shows that there is no God at all.

Is that a plausible answer, at least when considered from the hypothetical angle of Anselm's model of Satan's fall + the Biblical account of humanity's fall? In other words, if one is taking these Christian models of celestial and terrestrial history as serious proposals, at least for the sake of argument, will the PDH advocates' complaint about widespread nonbelief seem quite so compelling? In my opinion, no. Because viewed from the perspective of these Christian models, God's permission of a much greater degree of ignorance about Himself (indeed, even permission of ignorance about His very existence) is liable to seem a wholly rational application of the proverbial rule that "doing the same thing over and over again and expecting the same result is the very definition of madness." In other words, after two badly botched experiments, perhaps God has changed tactics. Perhaps He has decided that while He works towards our collective and individual redemptions it is better that, for now, we do not have indubitable awareness of what $\mathrm{He}$ is up to or even the fact that $\mathrm{He}$ is there. Maybe, for our own good, the strategy has shifted from the provision of maximal knowledge to the provision of, if not minimal knowledge, then a level of knowledge that is at any rate of a kind and degree well short of supplying certainty about either the truth of theism or God's plans for us and

\footnotetext{
${ }^{24}$ WiLliams, Anselm, 292-94.
} 
the world. So for now, most of us have to get by with: (x) hints and traces in the structure of the natural world; (y) an awareness of the basics of His moral law (revealed to us via our conscience); and, most importantly, (z) the testimonies of a smaller-but-still-substantial number among us, both today and historically, who have been graced with a far greater (if perhaps still rationally deniable) contact with Him. These lines of evidence, and perhaps others, suffice to render the leap of faith rational, but not rationally required. From our perspective this revelatory strategy might seem suboptimal and we may lament (with Anselm) the lack of direct experiential contact with God. But from God's perspective perhaps this is all that can be done in trying to make the best of a bad situation and in trying not to repeat past failures.

I doubt that many atheist advocates of the PDH will be particularly impressed by this reply. From their perspective, the whole Anselmian/Biblical background apparatus is likely to seem highly implausible, even when entertained merely as a thought experiment to probe a conceivable theistic defencebut-not-theodicy (to recall that distinction from the problem of evil literature). Though for some small segment openminded about that apparatus, this reply could be seen as carrying some weight. Of course a comprehensive defence of this Anselmian reply for the benefit of that segment would have to include a good deal more than what has been covered in this short paper (e.g., a discussion of the objection that sin might persist even in a state of total knowledge; or the aforementioned objection that the good of moral free choice cannot outweigh the evils it has wrought; or the objection that we today have the right to retry the experiment regardless of what happened in the past; or the objection that whatever the allegedly omnipotent God is doing to further our collective and individual redemptions could surely be accomplished just as effectively in a situation where His existence was indubitably obvious to all, etc.). I will leave that more comprehensive case to readers bitten by the Anselmian bug and eager to take up the gauntlet.

Still, perhaps in the end this Anselmian line of reasoning about ignorance and apparent divine absence is better interpreted not as a reply to the PDH (or at least not primarily as a reply to the PDH), but instead as falling within that other genre of inquiry briefly alluded to at the beginning of this paper: the genre of in-house Christian reflection on the ways of providence, on just what God might be up to in permitting widespread blameless agnosticism and atheism. Viewed from this vantage point, the idea is that this permission might have something to do with past events in salvation history, and thus might best be understood in light of that wider historical/theological vista. 
From that more theology-friendly angle I foresee an obvious objection, which goes like this: On the Anselmian/Biblical model God is being depicted far too anthropomorphically. The idea seems to be that God, faced with the angelic fall, had a "backup plan" in place when it came to the first humans (namely, give them even more knowledge, just short of hijacking their moral freedom); and then, when that plan failed, He had a further "backup plan" in place, namely giving the bulk of their descendants far less information while He worked out their salvation in comparatively subtle fashion, operating largely behind the scenes (incarnation in a humble carpenter in a backwater of the Roman Empire...) and then making that salvation known in likewise comparatively subtle fashion, working through human delegates (the Jewish people + the Church). But all this is talk of "backup plans" is silly. God is atemporal and providence does not work like this. God is not caught off guard by angelic or human failings and forced into contingency plans. The whole setup is misconceived.

In reply, I should emphasize that I am not suggesting that God was somehow caught unawares by the angelic fall, or Eve's. But these events did involve free creatures acting freely, and thus involved genuine contingency. God responds to our free choices and deals with contingencies, even if in an atemporal fashion appropriate to His nature and difficult for us to comprehend. By analogy, consider the longstanding debate in Christology between those who think that God would have become incarnate in Christ whether or not there had been a fall (i.e., those who think the incarnation was an original part of God's plan for the cosmos regardless of sin), versus those who think that God's incarnation in Christ was contingent on humanity's fall. Few claim that the latter camp is suggesting that God was caught off guard by humanity's sin, or that their stance involves some objectionable anthropomorphism regarding divine decision-making. Granted, how the divine consciousness and will tie back to time and contingency are immensely difficult topics for philosophical theology. But the Anselmian/Biblical model I have been entertaining here does not create any new problems or complications on this front.

Personally, I incline to the view that God's atemporality must somehow be compatible with a genuine responsiveness to human free will and historical contingency. I leave the details of how that works to better minds than mine, but the essential stance I favour is nicely summed up by Lossky:

With a certain excusable inexactitude, one could say that God in His providence condescends to the liberty of men. He acts as a result of this liberty, co-ordinating his actions with the acts of created beings, in order to govern the fallen universe by accomplishing His will without doing violence to the liberty of creatures. Therefore the mystery hidden 
before all ages in God and revealed to angels by the Church, ${ }^{25}$ this eternal and immutable foredetermination of the incarnation has at the same time a kind of contingency; one could almost say that it was occasional, provided this expression does not imply any idea of the unforeseen. ${ }^{26}$

These are deep waters, but hopefully that suffices to defuse the anthropomorphism allegation.

To sum up: Anselm's discussion of the fall of Satan makes important claims about the relationship between knowledge and moral freedom, claims foreshadowing later philosophical developments. When combined with some further reflections on the Biblical narrative of the fall of humanity, the Anselmian model of the devil's fall may shed light on wider providential history and on why it is that God has permitted, and continues to permit, widespread blameless agnosticism and atheism. This Anselmian approach may also make some headway in addressing Premise One of the PDH, at least among those advocates of the PDH who remain openminded towards the larger Christian worldview and account of salvation history. However, it is more likely to spark interest amongst theologians reflecting on that aforementioned providential history. In any case, the next time some stranger at a bus stop or in a grocery aisle asks you "wherein lies the contemporary relevance of studies in Anselmian demonology?" you will at least be equipped with a ready response.

\section{BIBLIOGRAPHY}

Athanasius. On the Incarnation of the Word. Translated by Archibald Robertson. Buffalo, NY: Christian Literature Publishing, 1892.

Augustine. On Free Choice of the Will. Translated by Thomas Williams. Indianapolis: Hackett, 1993.

AZADEGAN, Ebrahim. "Divine Love and the Argument from Divine Hiddenness." European Journal for Philosophy of Religion 6, no. 2 (2014): 101-16.

Chrysostom, John. Homilies on First Corinthians. Translated by Talbot W. Chambers. Buffalo, NY: Christian Literature Publishing, 1889.

COAKLEY, Sarah. "Divine Hiddenness or Dark Intimacy? How John of the Cross Dissolves a Contemporary Philosophical Dilemma." In Hidden Divinity and Religious Belief: New Perspectives, edited by Adam Green and Eleonore Stump, 229-45. Cambridge: Cambridge University Press, 2015.

CONFESSOR, Maximus. On Difficulties in Sacred Scripture: The Responses to Thalassios. Translated by Maximos Constas. Washington, DC: Catholic University of America Press, 2018.

\footnotetext{
${ }^{25}$ Here Lossky footnotes Ephesians 3:9-10.

${ }^{26}$ Vladimir Lossky, The Mystical Theology of the Eastern Church, translated from the original French by the Fellowship of St. Alban and St. Sergius (Crestwood: St. Vladimir's Seminary Press, 1957), 139.
} 
Damascene, John. On the Orthodox Faith. In Writings. Translated by Frederic Chase. Washington, DC: Catholic University of America Press, 1958.

Di CEGLIE, Roberto. "Christian Belief, Love for God, and Divine Hiddenness." Philosophia Christi 18, no. 1 (2016): 179-93.

DrANGE, Theodore. "The Argument from Non-Belief." Religious Studies 29, no. 4 (1993): 417-32.

Drange, Theodore. Nonbelief and Evil: An Argument for the Nonexistence of God. Amherst, NY: Prometheus, 1998.

DumsDay, Travis. "A Thomistic Response to the Problem of Divine Hiddenness." American Catholic Philosophical Quarterly 87, no. 3 (2013): 365-77.

GARCIA, Laura. "St. John of the Cross and the Necessity of Divine Hiddenness." In Divine Hiddenness: New Essays, edited by Daniel Howard-Snyder and Paul Moser, 83-97. Cambridge: Cambridge University Press, 2002.

Henry, Douglas. "Does Reasonable Nonbelief Exist?” Faith and Philosophy 18, no. 1 (2001): 75-92.

HEnRY, Douglas. "Reasonable Doubts about Reasonable Nonbelief." Faith and Philosophy 25, no. 3 (2008): 276-89.

JACKSON, Elisabeth. "Wagering against Divine Hiddenness." European Journal for Philosophy of Religion 8, no. 4 (2016): 85-108.

KELLER, James. "The Hiddenness of God and the Problem of Evil." International Journal for Philosophy of Religion 37, no. 1 (1995): 13-24.

KING, Rolfe. Obstacles to Divine Revelation: God and the Reorientation of Human Reason. London: Continuum, 2008.

Lossky, Vladimir. The Mystical Theology of the Eastern Church. Crestwood, New York: St. Vladimir's Seminary Press, 1957.

Maitzen, Stephen. "Divine Hiddenness and the Demographics of Theism." Religious Studies 42, no. 2 (2006): 177-91.

MArCAR, G. P. “Aquinas' Quinque Viae: Fools, Evil, and the Hiddenness of God.” Heythrop Journal 56, no. 1 (2015): 67-75.

Morris, Thomas V. Making Sense of It All: Pascal and the Meaning of Life. Grand Rapids, MI: Eerdmans, 1992.

MurRay, Michael. “Deus Absconditus.” In Divine Hiddenness: New Essays, ed. Daniel Howard-Snyder and Paul Moser, 62-82. Cambridge: Cambridge University Press, 2002.

NAZIAnZus, Gregory. Orations. Translated by Charles G. Browne and James E. Swallow. Buffalo, NY: Christian Literature Publishing, 1894.

Nemoianu, V. Martin. "Pascal on Divine Hiddenness.” International Philosophical Quarterly 55, no. 3 (2015): 325-43.

Origen, On First Principles. Translated by Frederick Crombie. Buffalo, NY: Christian Literature Publishing, 1885

PAytas, Tyler. "Of Providence and Puppet Shows: Divine Hiddenness as Kantian Theodicy." Faith and Philosophy 36, no. 1 (2019): 56-80.

Pseudo-Dionysius. The Celestial Hierarchy. In Pseudo-Dionysius: The Complete Works, translated by Colm Luibheid, 260C-261D. Mahwah, NJ: Paulist Press, 1987.

Rogers, Katherin. Anselm on Freedom. Oxford: Oxford University Press, 2008.

RoGERS, Katherin. Freedom and Self-Creation: Anselmian Libertarianism. Oxford: Oxford University Press, 2015 
Rogers, Katherin. Perfect Being Theology. Edinburgh: Edinburgh University Press, 2000.

ROGERS, Katherin. The Neoplatonic Metaphysics and Epistemology of Anselm of Canterbury. Lewiston, NY: Edwin Mellen Press, 1997.

Schellenberg, J. L. Divine Hiddenness and Human Reason. Ithaca, NY: Cornell University Press, 1993.

SChellenberg, J. L. The Hiddenness Argument: Philosophy's New Challenge to Belief in God. Oxford: Oxford University Press, 2015.

SchellenberG, J. L. The Wisdom to Doubt: A Justification of Religious Skepticism. Ithaca, NY: Cornell University Press, 2007.

Swinburne, Richard. Providence and the Problem of Evil. Oxford: Oxford University Press, 1998. Swinburne, Richard. The Existence of God, 2nd ed. Oxford: Oxford University Press, 2004.

WiLliams, Thomas, trans. Anselm: Basic Writings. Indianapolis, IN: Hackett, 2007.

\author{
FROM SATAN'S WAGER TO EVE'S GAMBIT TO OUR LEAP: \\ AN ANSELMIAN REPLY TO THE PROBLEM OF DIVINE HIDDENNESS
}

\title{
S u m m a r y
}

While St. Anselm does not supply us with an explicit discussion of the problem of divine hiddenness (PDH) as it is typically conceived today - namely, as an argument for atheism - he is keenly aware of the existential difficulty posed by our seeming lack of access to God. Moreover, he provides the ingredients for an interesting and heretofore neglected approach to the PDH, one rooted in multiple Christian narratives about lapses from knowledge-infused states of grace, both angelic and human. The goal of this paper is to draw out that Anselmian approach explicitly, and to provide at least a rudimentary assessment of it.

Keywords: Agnosticism; angels; Anselm; atheism; Bible; demons; devil; doubt; God; hiddenness; Satan, theism.

\section{OD ZAKŁADU SZATANA, PRZEZ PODSTĘP EWY, DO NASZEGO SKOKU: ANZELMIAŃSKA ODPOWIEDŹ NA PROBLEM BOŻEGO UKRYCIA}

\section{Streszczenie}

Chociaż u św. Anzelma nie znajdziemy wyraźnej dyskusji na temat problemu Bożego ukrycia (PBU), tak jak jest on dziś powszechnie rozumiany - mianowicie jako argument za ateizmem - to jest on doskonale świadomy trudności egzystencjalnych, jakie stwarza nasz pozorny brak dostępu do Boga. Co więcej, dostarcza on składników dla interesującego i dotychczas zaniedbanego podejścia do PBU, zakorzenionego w wielu chrześcijańskich narracjach o odstępstwach od stanu łaski, zarówno anielskich, jak i ludzkich. Celem tego artykułu jest wyraźne nakreślenie podejścia Anzelma i dostarczenie przynajmniej szczątkowego jego rozwiązania PBU.

Słowa kluczowe: agnostycyzm; aniołowie; Anzelm; ateizm; Biblia; wątpliwość; Bóg; ukrytość; szatan; teizm. 